\title{
PŘEHLED AKTUÁLNÍ JUDIKATURY II/2019
}

DOMINIKA COLLETT, FRANTIŠEK KASL, JAKUB KLODWIG, IVANA KUDLÁČKOVÁ, PAVEL LOUTOCKÝ, JAKUB MÍŠEK, TEREZA NOVOTNÁ, ANNA STÁRKOVÁ, JAN SVOBODA, PETRA VYDROVÁ, JAN ZIBNER

\section{ELEKTRONICKÉ KOMUNIKACE \& ISP}

\section{SLUŽBA VOLÁNÍ PŘES INTERNETOVÝ PROTOKOL (VOIP) JAKO SLUŽBA ELEKTRONICKÝCH KOMUNIKACÍ}

Soud: $\quad$ Soudní dvůr Evropské unie

Věc: $\quad$ C-142/18 (Skype)

Datum: $\quad$ 5. 6. 2019

Dostupnost: curia.europa.eu

Společnost Skype zavedla funkci SkypeOut umožňující uskutečňovat telefonní volání z koncového zařízení na pevnou linku nebo na mobilní telefon za použití internetového protokolu (IP), a to technikou zvanou „Voice over IP“ (VoIP). Belgický úřad pro poštovní a telekomunikační služby uložil společnosti Skype správní pokutu, protože se Skype řádně neoznámil poskytovanou službu elektronických komunikací. Skype podal návrh na zrušení rozhodnutí a domáhal se určení, že SkypeOut není službou elektronických komunikací a Skype tak není poskytovatelem služeb elektronických komunikací.

Soudní dvưr byl tázán, zda musí být čl. 2 písm. c) směrnice 2002/21/ES („rámcová směrnice“), vykládán v tom smyslu, že poskytuje-li výrobce 
softwaru funkci nabízející službu VoIP, musí být tato služba kvalifikována jako služba elektronických komunikací.

Soudní dvůr uvedl, že pro kvalifikaci služby jako služby elektronických komunikací není rozhodující, že k přenosu signálu dochází prostřednictvím infrastruktury, která poskytovateli služeb nepatří. ${ }^{1}$ Soudní dvůr došel k závěru, že společnost Skype nabízí službu VoIP, pobírá od uživatelů služby úplatu a je vůči nim odpovědná za přenos hlasových signálů, a to na základě smluv uzavřených s poskytovateli telekomunikačních služeb. ${ }^{2}$ Dále uvedl, že i když má uživatel funkce SkypeOut přístup ke službě prostřednictvím připojení na Internet, kterou poskytuje ISP a která je sama o sobě službou elektronických komunikací, neznamená to, že služba VoIP nemůže být kvalifikována jako služba elektronických komunikací. ${ }^{3}$ Přestože služba VoIP předpokládá dvě různé služby, kdy jedna spadá do odpovědnosti ISP volajícího uživatele a druhá do společné odpovědnosti poskytovateli̊ telekomunikačních služeb volaných osob a společnosti Skype, ${ }^{4}$ odpovědnost za službu VoIP nese společnost Skype, nebot ji poskytuje za úplatu svým zákazníkům. ${ }^{5}$ Skutečnost, že SkypeOut je jednou z funkcí softwaru Skype není pro kvalifikaci služby VoIP jako služby elektronických komunikací rozhodující, nebot Skype a SkypeOut se jasně liší co do svého předmětu a ve svém fungování jsou navzájem zcela autonomní. ${ }^{6}$ Klauzule ve všeobecných obchodních podmínkách o nenesení odpovědnosti za přenos signáli̊n, nemůže mít vliv na kvalifikaci služby VoIP jako služby elektronických komunikací. ${ }^{7}$ Též skutečnost, že služba VoIP poskytovaná funkcí SkypeOut spadá rovněž pod pojem služba informační společnosti, neznamená, že by nemohla být kvalifikována jako služba elektronických komunikací. $^{8}$

\footnotetext{
Srov. bod 29 anotovaného rozhodnutí.

Srov. bod 31, 33 a 35 anotovaného rozhodnutí.

3 Srov. 37 anotovaného rozhodnutí.

4 Srov. bod 38 anotovaného rozhodnutí.

5 Srov. bod 40 anotovaného rozhodnutí.

6 Srov. bod 43 anotovaného rozhodnutí.

7 Srov. bod 44 anotovaného rozhodnutí.

8 Srov. bod 46 anotovaného rozhodnutí.
} 
Soudní dvůr tedy dospěl k závěru, že poskytuje-li výrobce softwaru funkci nabízející službu VoIP, která uživateli umožňuje volat z koncového zařízení na číslo pevné linky nebo mobilního telefonu prostřednictvím veřejné telefonní sítě některého členského státu, jedná se o službu elektronických komunikací ve smyslu rámcové směrnice, pokud výrobce pobírá za poskytování uvedené služby úplatu a pokud poskytování této služby předpokládá uzavření smluv mezi tímto výrobcem a poskytovateli telekomunikačních služeb.

Autorka: IK

\author{
Soud: $\quad$ Soudní dvůr Evropské unie \\ Věc: $\quad$ C-193/18 (Google) \\ Datum: $\quad$ 13. 6. 2019 \\ Dostupnost: curia.europa.eu
}

GMAIL JAKO SLUŽBA ELEKTRONICKÝCH KOMUNIKACÍ

V původním sporu proti sobě stála německá Spolková agentura pro elektrické, plynofikační, telekomunikační, poštovní a železniční sítě (dále jen „spolková agentura“) a společnost Google, která provozuje elektronickou službu Gmail soužící k emailové komunikaci. Spolková agentura měla za to, že služba Gmail je službou elektronických komunikací dle platných německých i unijních předpisů, a tudíž na ni dopadá ohlašovací povinnost. Proti tomuto správnímu rozhodnutí podal Google stížnost, a následně správní žalobu. Správní soud žalobu zamítl s tím, že přenos emailů (odesílání a doručování), který poskytuje společnost Google, je přenosem signálů i přesto, že tento přenos probíhá přes internetové připojení, které poskytuje jiná služba ISP a ne Google samotný. Google se odvolal k německému Nejvyššímu správnímu soudu spolkové země Severní Porýní-Vestfálsko (dále jen „předkládající soud“) s hlavním argumentem, že nezařizuje přenos signálů, který zařizuje jiná ISP, a tudíž na něj nespadá ohlašovací povinnost.

SDEU se zabýval předběžnou otázkou, která se týkala výkladu pojmu přenos signálů jako definičního znaku služby elektronických komunikací. 
SDEU posuzoval, zda je přenosem signálů internetová emailová služba, která je založena na odesílání a přijímaní signálů skrz otevřený internet, ale sama nezajištuje přístup $\mathrm{k}$ internetu, a tudíž faktický přenos těchto signálů.

Služba elektronických komunikací je definována zejména v čl. 2 písm. c) směrnice Evropského parlamentu a Rady 2002/21/ES ze dne 7. března 2002 o společném předpisovém rámci pro sítě a služby elektronických komunikací (rámcová směrnice), kde je uvedeno „[...] ,službou elektronických komunikací se rozumí služba obvykle poskytovaná za úplatu, která spočtvá zcela nebo převážně v přenosu signálů po sitích elektronických komunikací [...]“.

SDEU dovozuje, že provozování internetové emailové služby je nesporně př̀nosem signálů, nicméně nejedná se o službu elektronických komunikací ve smyslu čl. 2 písm. c) rámcové směrnice, nebot se tato služba nespočívá „zcela nebo převážně $v$ přenosu signálư“. ${ }^{9}$ Odpovědnost za přenos signálů mají dle Soudního dvora poskytovatelé zejména „správci různých sítí tvořících otevřený Internet “"10 a ani to, že má Google vliv na prijímání a odesílání emailových zpráv není dostatečným pro zařazení této společnosti mezi službu elektronických komunikací. ${ }^{11}$

SDEU shrnul, že internetová emailová služba, která nezajištuje př́stup $\mathrm{k}$ internetu, ale pouze poskytuje odesílání a přijímání emailů přes internet pak nespočívá „zcela či převážně v přenosu signálü“ a nemůže se tedy jednat o službu elektronické komunikace a Google tedy nemá ohlašovací povinnost. $^{12}$

Autorka: TN

\footnotetext{
9 Odst. 34 a 35 anotovaného rozhodnutí.

10 Odst. 36 anotovaného rozhodnutí.

11 Odst. 37 anotovaného rozhodnutí.

12 Odst. 41 a 43 anotovaného rozhodnutí.
} 


\title{
MOŽNOST SOUDU ULOŽIT PŘEDBĚŽNÝM OPATŘENÍM POSKYTOVATELI HOSTINGU POVINNOST ODSTRANĚNÍ STEJNÉHO ČI ROVNOCENNÉHO OBSAHU FORMOU DOHLEDU A VYHLEDÁVÁNí V CELOSVĚTOVÉM ROZSAHU
}

\author{
Soud: $\quad$ Soudní dvůr Evropské unie \\ Věc: $\quad$ C-18/18 (Glawischnig-Piesczek) \\ Datum: $\quad 3.10 .2019$ \\ Dostupnost: curia.europa.eu
}

Podkladem případu byl příspěvek uživatele na sociální síti Facebook z dubna 2016, kterým byl sdílen odkaz na článek na rakouském portálu oe24.at o kontroverzním politickém postoji die Grünen (Zelení), pod kterým algoritmus Facebooku v rámci shrnutí obsahu článku zobrazil fotografii Evy Glawischnig-Piesczek, která je předsedkyní jejich poslaneckého klubu. ${ }^{13}$ Ta toto její propojení s daným postojem vnímala jako urážku na cti a po bezvýsledné komunikaci se společností Facebook podala žalobu u rakouského soudu.

Soud vydal v prosinci 2016 př̀dběžné opatření, aby se společnost Facebook do pravomocného rozsudku zdržela zveřejňování fotografie žalobkyně ve spojení s př́spěvky stejného či rovnocenného obsahu. ${ }^{14}$ Odvolacím soudem byl rozsah povinnosti omezen pouze na stejné či ohlášené příspěvky. Spor tak doputoval před Oberster Gerichtshof (Nejvyšší soud), který položil předběžné otázky SDEU. ${ }^{15}$

Ty se týkaly př́pustného obsahového a teritoriálního rozsahu povinnosti na odstranění obsahu, která může být uložena soudem poskytovateli hostingu, zde společnosti Facebook, s přihlédnutím k vyloučení obecné povinnosti poskytovatelů hostingu dohlížet na přenášený a ukládaný obsah skrze čl. 15 směrnice o elektronickém obchodu. ${ }^{16}$

\footnotetext{
13 Body 10-12 anotovaného rozhodnutí.

14 Bod 14 anotovaného rozhodnutí.

15 Body 16-19 anotovaného rozhodnutí.
} 
SDEU předně podotkl, že je přípustnost uložení soudních příkazů v podobě předběžného opatření na základě vnitrostátního práva předvídána čl. 14 odst. 3 a čl. 18 směrnice o elektronickém obchodu. ${ }^{17}$ Dále pak potvrdil, že posuzovací pravomoc ohledně provádění těchto prostředků soudní ochrany přísluší v souladu s čl. 18 odst. 1 směrnice členským státům a některá jazyková znění zde obsahují velmi otevřenou formulaci přípustného rozsahu daných opatření. ${ }^{18}$ SDEU pak výsledně dovodil, že zákaz obecné povinnosti dohlížet na hostovaný obsah se v souladu s bodem 47 odůvodnění směrnice netýká povinnosti uložené v konkrétním případě ve vztahu ke konkrétní informaci. ${ }^{19} \mathrm{~V}$ případě příspěvků se stejným obsahem je pak soud takto oprávněn po poskytovateli požadovat odstranění bez ohledu na to, kdo požádal o její uložení, ${ }^{20}$ tedy celosvětově. ${ }^{21}$ Shodný závěr Soudní dvůr dovodil i pro příspěvky $s$ informací rovnocenného obsahu, ačkoliv daný soudní příkaz musí být dostatečně specifikován. ${ }^{22}$ Pokud tedy dané soudní opatření ukládá dostatečně konkrétně vymezený stejný či rovnocenný obsah, který má být odstraněn, tak aby poskytovatel nebyl nucen uvedený obsah samostatně posuzovat, není nepřiměřené soudem požadovat, aby poskytovatel hostingu $\mathrm{v}$ tomto rozsahu prováděl dohled a vyhledávání daného obsahu v rámci svých (automatizovaných) kapacit. $^{23}$

Rozhodnutí ve svém důsledku posiluje soudní ochranu proti zásahům do práv skrze obsah na sociálních sítích či jiných hostingových službách, jelikož jednoznačně zakotvuje plnou šíři opatření, ke kterým je soud $\mathrm{v}$ tomto směru oprávněn.

Autor: FK

\footnotetext{
16 Směrnice Evropského parlamentu a Rady 2000/31/ES ze dne 8. června 2000 o některých právních aspektech služeb informační společnosti, zejména elektronického obchodu, na vnitřním trhu.

17 Body 24-27 anotovaného rozhodnutí.

18 Body 29-30 anotovaného rozhodnutí.

19 Body 34-35 anotovaného rozhodnutí.

20 Bod 37 anotovaného rozhodnutí.

21 Bod 50 anotovaného rozhodnutí.

22 Body 38-47 anotovaného rozhodnutí.

23 Body 45-46 anotovaného rozhodnutí.
} 


\title{
EGOVERNMENT
}

\author{
ZAŘAZENÍ IP ADRESY SPRÁVNÍM ORGÁNEM NA BLACK-LIST \\ Soud: $\quad$ Nejvyšší správní soud České republiky \\ Věc: $\quad 2$ As $153 / 2018-31$ \\ Datum: $\quad$ 6. 3. 2019 \\ Dostupnost: nssoud.cz
}

Stěžovatel se v původním sporu domáhal ochrany před nezákonným zásahem žalovaného - Městského úřadu Domažlice. Stěžovatel se domníval, že žalovaný nezákonně zasáhl do jeho práv tím, že se jeho emailová adresa, kterou využil k podání $\mathrm{k}$ žalovanému, objevila na tzv. black-listu žalovaného a kvůli tomu mu podání nebylo vůbec doručeno, o čemž byl stěžovatel informován prostřednictvím svého poskytovatele emailové služby (email s podáním nebyl doručen adresátovi). Ačkoliv byl stěžovatel informován, jiné podání už neučinil a tím promeškal procesní lhůtu.

Stěžovatel nejprve reagoval na situaci podáním žaloby na ochranu před nezákonnými zásahy žalovaného ke Krajskému soudu v Plzni. Stěžovatel se domáhal určení, že zařazení jeho emailové adresy na tzv. black-list je nezákonným postupem Městského úřadu a domáhal se zdržení a zrušení rozhodnutí žalovaného. ${ }^{24}$

Nejvyšší správní soud se zabýval otázkou, zda zařazení emailové adresy správním orgánem na tzv. black-list, který navíc spravuje externí soukromá společnost, je postup v souladu se zákonem.

Podání učiněné elektronicky ve správním řízení upravuje § 19 odst. 4, 9 a 10 zákona č. 500/2004 Sb., správního řádu.

Stěžovatel argumentuje především tím, že správní orgán de facto odmítnul přijmout jeho podání, ovšem tím, že mohl vůbec vykonat akt „odmítnutí“ tak je prokázáno, že podání bylo doručeno, tedy dostalo se do dispoziční sféry adresáta (odmítnutí je také disponováním s podáním)

24 Odst. 1 anotovaného rozhodnutí. 
a lhůta tedy byla dodržena. ${ }^{25}$ Druhým nosným argumentem stěžovatele bylo to, že jde na vrub správního orgánu, pokud se rozhodne pověřit zabezpečením své emailové schránky externí soukromou společnost a kvůli tomu nepřijme včasné a řádně odeslané podání. Není možné, aby taková situace šla na vrub stěžovateli, který podal své podání včas a řádným způsobem (skrz emailovou schránku správního orgánu). ${ }^{26}$ NSS jeho argumentaci odmítl a zamítl kasační stížnost jako nedůvodnou. ${ }^{27}$ Dle NSS zařazení emailové adresy na tzv. black-list znamená, že rozhodnutí ani nedorazí do dispoziční sféry orgánu, protože je zastaveno a vráceno ještě před doručením, o čemž je odesílatel také řádně informován. ${ }^{28}$ Dle NSS je dále naopak žádané, aby správní orgány využívaly pro zabezpečení elektronických schránek služeb soukromých profesionálních společností, a dále také jde na vrub stěžovatele, že zvolil tento způsob podání, který je méně privilegovaný než datová schránka či podání doručení poštou a jedná se o jeho volbu využít soukromou společnost, jejíž server byl správním orgánem zablokován pro doručování. ${ }^{29}$

Autorka: TN

\section{E-MAIL A PÍSEMNÁ FORMA}

Soud: $\quad$ Nejvyšší soud České republiky

Věc: $\quad 23$ Cdo $\quad 3439 / 2018$

Datum: $\quad$ 16. 5. 2019

Dostupnost: nsoud.cz

Žalobce (česká obchodní korporace) sjednala se španělskou společností (žalovanou) e-mailem smlouvu o dílo, jejíž součástí byla rovněž rozhodčí doložka. Žalovaná společnost nicméně nerespektovala platnost rozhodčí doložky $\mathrm{v}$ rámci vzniklého sporu a nebyla ochotna se tak účastnit

\footnotetext{
25 Odst. 6 anotovaného rozhodnutí.

26 Odst. 7 anotovaného rozhodnutí.

27 Odst. 18 anotovaného rozhodnutí.

28 Odst. 14 anotovaného rozhodnutí.

29 Odst. 15, 16 a 17 anotovaného rozhodnutí.
} 
rozhodčího řízení. Namítala, že nedošlo k platnému sjednání rozhodčí smlouvy, když nebyla podepsána kvalifikovaným elektronickým podpisem.

Spor projednávaly místně př́slušné české soudy a jak prvostupňový, tak odvolací soud rozhodly, že se $\mathrm{v}$ daném př́ípadě jednalo o platně uzavřenou rozhodčí doložku. Proto se žalovaná dovolala k Nejvyššímu soudu.

Nejvyšší soud posuzoval, jestli uzavřením e-mailem došlo k naplnění podmínky pro uzavření rozhodčí smlouvy písemnou formou. Toto Nejvyšší soud posuzoval zejména v souvislosti s požadavkem, který je jednak kladen zákonem č. 216/1994 Sb., o rozhodčím řízení a o výkonu rozhodčích nálezů, ve znění pozdějších předpisů, ale rovněž Newyorkskou úmluvou ${ }^{30}$ a Evropskou úmluvou o mezinárodní obchodní arbitráži. ${ }^{31}$ Ve všech těchto závazných pramenech práva je stanoveno velmi obdobně, ${ }^{32}$ že ,písemná forma je zachována i tehdy, je-li rozhodči smlouva sjednána telegraficky, dálnopisem nebo elektronickými prostředky, jež umožňují zachycení jejich obsahu a určení osob, které rozhodčí smlouvu sjednaly". ${ }^{33}$ Postupným zkoumáním podstaty soud nejprve určil, že se na danou věc bude aplikovat Newyorkská úmluva, poté odkázal na UNCITRAL Recommendation ze dne 7. 7. 2006, které jednoznačně shrnuje, že daný výčet (“dálnopisem, telegraficky”) je demonstrativní a v době tvorby Newyorkské úmluvy nebyla předpokládána existence internetu. To ale neznamená, že by nemohla být daným zpo̊sobem rozhodčí smlouva uzavřena. Newyorská úmluva tak dle Nejvyššího soudu zahrnuje i výměnu komunikace prostřednictvím e-mailu. Soud dále ještě zdůraznil, že pro platné uzavření rozhodčí smlouvy by požadavek na využití kvalifikovaného elektronického podpisu byl excesivní.

Soud tak dovolání španělské žalované zamítl.

Autor: PL

\footnotetext{
30 Vyhláška č. 74/1959 Sb. ze dne 6. listopadu 1959 o Úmluvě o uznání a výkonu cizích rozhodčích nálezů (Newyorská úmluva).

31 Vyhláška č. 176/1964 Sb., vyhláška ministra zahraničních věcí o Evropské úmluvě o obchodní arbitráži.

32 Faktická textace je v rámci těchto uvedených pramenů jiná, význam a požadavky jsou ale stejné.

${ }^{33}$ Viz anotované rozhodnutí.
} 


\section{E-MAIL A PÍSEMNÁ FORMA (OPĚT, ALE ŠPATNĚ)}

Soud: $\quad$ Nejvyšší soud České republiky

Věc: $\quad 26$ Cdo $1230 / 2019$

Datum: 22. 5. 2019

Dostupnost: nsoud.cz

Toto vcelku krátké usnesení se zabývalo podmínkami, které je nutno splnit pro dodržení písemné formy kladené zákonem č. 89/2012 Sb., občanský zákoník, ve znění pozdějších předpisů (dále jen „OZ“) při využití e-mailu.

Žalobkyně proti výpovědi z nájmu podala námitky e-mailem, odvolací soud však zdůraznil, že takovéto podání námitek nesplnilo požadavek na písemnou formu dle $\S 2314$ OZ. Zdůraznil pak, že pro zachování písemné formy (dle § 562 OZ) by bylo nutno doplnit e-mail o elektronický podpis.

Nejvyšší soud se tak zabýval tím, jestli byly $v$ daném případě splněny dvě náležitosti pro zachování formy, a to písemnost a podpis. Podmínku písemnosti soud shrnul jen ve smyslu, že dané jednání je zachyceno v písemném textu listiny. Nezabýval se již ale nijak tím, co znamená pojem „písemné“ (jedná se rovněž o elektronickou formu - pozn. autor) a pojem „listina“ (zde se může ve spojení s § 3016 odst. 1 OZ jednat opět o elektronickou formu). Jediným argumentem soudu $\mathrm{k}$ podpisu bylo, že „vznesla-li žalobkyně Námitky e-mailem [...], který nebyl opatřen elektronickým podpisem, je závěr odvolacího soudu, že nedodržela písemnou formu Námitek, v souladu s judikaturou Nejvyššího soudu. “34 Judikaturu soud pak jen obecně shrnuje bez jakékoli analýzy konkrétních aspektů.

Soud tak shrnul, že e-mail, který nebyl podepsán elektronickým podpisem nemůže naplnit písemnou formu.

Na rozhodnutí je nutno pohlížet kriticky zejména v souvislosti s tím, že se soud nijak nezabýval otázkou, co elektronický podpis je a zejména nezjištoval, jestli žalovaná námitku neopatřila „prostým“ elektronickým podpisem. Už v tom případě by dané naplnilo podmínku podpisu. ${ }^{35}$ Rovněž je možné rozhodnutí kritizovat i pro jeho rigidní výklad, jelikož tímto

\footnotetext{
${ }^{34}$ Anotované rozhodnutí.
} 
rozhodnutím bylo žalované následně de facto upřeno právo na spravedlivý prístup $\mathrm{k}$ soudu. Rozhodnutí je tak nutno považovat za špatné a matoucí. Anotované rozhodnutí ukazuje, že $\mathrm{v}$ některých př́padech $\mathrm{v}$ problematice elektronické identifikace a kontraktace stále tápou i vyšší soudy.

Autor: PL

\author{
ELEKTRONICKÝ PODPIS A ÚŘEDNÍ OVĚŘENÍ PODPISU \\ Soud: $\quad$ Nejvyšší soud České republiky \\ Věc: $\quad$ KSPH 64 INS 26339/2015, 29 NSČR 133/2017-B-36 \\ Datum: $\quad$ 30. 7. 2019 \\ Dostupnost: isir.justice.cz
}

Anotované rozhodnutí se zabývalo velmi zajímavou otázkou vzájemné souvislosti elektronického podpisu (resp. některého $\mathrm{z}$ jeho typů) s úředním ověřením podpisu.

Věritel v rámci insolvenčního řízení podal hlasovací lístek pro oddlužení zpeněžením majetkové podstaty prostřednictvím datové schránky (lístek byl podepsán zaručeným (sic!) elektronickým podpisem). Dle nižších soudů ale v souvislosti s § 97 odst. 2 zákona č. 182/2006 Sb., o úpadku a způsobech jeho řešení (insolvenční zákon), ve znění od 1. 1. 2014 do 18. 9. 2016 (dále jen „IZ“) nedošlo takovým podáním k naplnění podmínky požadované zákonem - hlasovací lístek je nutno opatřit úředně ověřeným podpisem nebo elektronicky s využitím uznávaného elektronického podpisu ( v současné chvíli je ekvivalentem kvalifikovaný elektronický podpis).

Nejvyšší soud se tak v daném případě zabýval otázkou, jestli je možné, aby vůbec nějaký typ elektronického podpisu (at̉ už se jedná o zaručený nebo kvalifikovaný elektronický podpis) naplnil požadavek úředního ověření a za jakých podmínek.

\footnotetext{
K tomu částečně viz např́klad LOUTOCKÝ, Pavel. Ochrana spotřebitele při uzavírání smluv na internetu a možnost řešení vzniklých sporů online. In: POLČÁK, Radim et al. Právo informačních technologií. 2018. Praha: Woltes Kluwer. S. 307 a násl. nebo POLČÁK, R. Elektronické právní jednání - změny, problémy a nové možnosti v zákoněč. 89/2012 Sb. Bulletin advokacie. 2014, č. 13, s. 34-41.
} 
Nejvyšší soud zdůraznil, že úřední ověření je úzce vymezeným institutem, který je zákonem jasně definován. ${ }^{36}$ Soud dále poměrně vhodně rozvedl jednotlivé druhy podpisů, správně identifikoval, že zaručený elektronický podpis je jen předstupněm kvalifikovaného elektronického podpisu (rozebral poměrně kvalitně i dopady nařízení eIDAS, které upravuje problematiku elektronické identifikace), odkázal na odbornou literaturu a shrnul, že požadavek úředního ověření podpisu obecně vylučuje možnost využít elektronický podpis, jelikož chybí v českém právu takové zákonné propojení. ${ }^{37}$ To bylo ale explicitně zakotveno v určitou dobu IZ.

Nejvyšší soud tak uzavřel, že v daném případě nebyly požadavky na formu podání splněny, jelikož nebylo využito adekvátního typu elektronického podpisu.

Dané rozhodnutí je zajímavé tím, že poměrně přehledně vymezuje jednotlivé druhy podpisu a rozebírá je do detailu. Je dále nutno upozornit, že fakticky není důvod, aby kvalifikovaný elektronický podpis nemohl být kladen na roveň úřednímu ověření. Přestože daná úprava $\mathrm{v}$ IZ již není bohužel účinná, připravovaný zákon o právu na digitální služby ${ }^{38}$ by měl obecně zakotvit předpoklad, že úřední ověření bude moci být nahrazeno právě kvalifikovaným elektronickým podpisem.

Autor: PL

\section{PRÁVO DUŠEVNÍHO VLASTNICTVÍ}

\section{LOCUS DELICTI PŘI UŽITÍ OCHRANNÉ ZNÁMKY NA INTERNETU}

Soud: $\quad$ Soudní dvůr Evropské unie

Věc: $\quad$ C-172/18 (AMS Neve)

Datum: $\quad$ 5. 9.2019

Dostupnost: curia.europa.eu

36 Strana 10 anotovaného rozhodnutí.

37 Strana 8 anotovaného rozhodnutí.

38 Sněmovní tisk 447. N.z. o právu na digitální služby [online]. Poslanecká sněmovna České republiky [vid. 16. 11. 2019]. Dostupné z: http://www.psp.cz/sqw/historie.sqw? $\mathrm{o}=8 \& \mathrm{t}=447$. 
Žádost o předběžné otázky byla předložena v rámci sporu mezi britskými společnostmi AMS Neve Ltd, Barnett Waddingham Trustees a Markem Crabtreem na straně jedné (dále jen „žalobci“) a španělskou společností Heritage Audio SL a Pedrem Rodríguez Arribasem na straně druhé (dále jen „žalovaní). Dne 15. října 2015 podali žalobci u soudu pro duševní vlastnictví a podnikání ve Spojeném království žalobu pro porušení práv plynoucích z ochranné známky EU. Žalovaným bylo vytýkáno, že nabízeli $\mathrm{k}$ prodeji spotřebitelům ve Spojeném království napodobeniny výrobků společnosti AMS Neve označených totožnou nebo podobnou ochrannou známkou EU žalobců. Na podporu žaloby žalobci předložili různé dokumenty, mimo jiné screenshoty internetových stránek, účtů Facebook a Twitter společnosti Heritage Audio.

Žalovaní vznesli námitku nepř́ślušnosti soudu, kterému byla tato věc předložena. Soud pro duševní vlastnictví a podnikání určil, že není příslušný $\mathrm{k}$ projednání této žaloby pro porušení $\mathrm{v}$ rozsahu, $\mathrm{v}$ němž se zakládá na dotčené ochranné známce EU. Žalovaní podali proti tomuto rozsudku odvolání u odvolacího soudu pro Anglii a Wales.

Spor spočíval v otázce, jaké národní soudy jsou př́slušné pro řešení daného případu. Předběžné otázky předložené Soudnímu dvoru se týkaly zejména výkladu čl. 97 odst. 5 nařízení č. 207/2009, ${ }^{39}$ dle kterého řízení mohou být rovněž vedena před soudy členského státu, na jehož území k porušení došlo.

Soudní dvưr EU připomněl, že ustanovení čl. 97 odst. 5 nařízení č. 207/2009 působí pro př́pady žalob o ochranné známky EU jako lex specialis vůči nařízení $1215 / 2012 .{ }^{40}$ Pro určení působnosti národního soudu proto bylo nezbytné vyložit formulaci „[členský stát], na jehož území $k$ porušení došlo“. V případě, že vytýkané jednání spočívá jako v projednávaném případě v reklamách a nabídkách k prodeji zobrazovaných elektronickými prostředky (např́klad na webových

\footnotetext{
39 Nařízení Rady (ES) č. 207/2009 ze dne 26. února 2009 o ochranné známce Společenství (dále jen „nařízení č. 207/2009“).

40 Bod 34 anotovaného rozhodnutí.
} 
stránkách, a sítích Twitter a Facebook), je nutné dovodit, ${ }^{41}$ zda k tomuto jednání došlo na území, kde se nacházejí spotřebitelé nebo podnikatelé, kterým jsou tyto reklamy a nabídky k prodeji určeny. Není přitom podstatné, že žalovaný má sídlo nebo bydliště na jiném území, že se server elektronické sítě, který žalovaný používá, nachází na jiném územín ${ }^{42}$ nebo že třetí osoba učinila rozhodnutí a opatření za účelem tohoto elektronického zobrazování v jiném členském státě. ${ }^{43}$

Autorka: DC

\section{NEPLATNOST OCHRANNÉ ZNÁMKY TVOŘENÉ TVAREM RUBIKOVY KOSTKY}

Soud: Soudní dvůr Evropské unie

Věc: T-601/17 (Rubik's Brand Ltd)

Datum:

24. 10. 2019

Dostupnost: curia.europa.eu

V roce 1999 byla registrována ${ }^{44}$ evropská ochranná známka Rubikovy kostky. ${ }^{45}$ Následně bylo společností Simba Toys GmbH \& Co. KG („Simba Toys“) postupně iniciováno několik pro tuto společnost neúspěšných řízení směřujících k prohlášení ochranné známky za neplatnou. ${ }^{46}$ To mělo dle Simba Toys nastat $\mathrm{z}$ absolutních důvodi̊ pro zamítnutí zápisu ochranné známky, mimo jiné s odkazem na skutečnost, že do rejstříku nemohou být zapsané takové známky, které jsou tvořeny výlučně tvarem nebo jinou vlastností výrobku, jež jsou nezbytné pro dosažení technického výsledku. ${ }^{47}$

Na základě kasačního opravného prostředku podaného Simba Toys v roce 2016 k Soudnímu dvoru tento napadené rozhodnutí odvolacího

\footnotetext{
41 Soudní dvůr EU odkázal na předchozí judikaturu, srov. bod 63 rozsudku ze dne 12. července 2011, L'Oréal a další, C-324/09.

42 Bod 47 anotovaného rozhodnutí.

43 Bod 65 anotovaného rozhodnutí.

44 Jejím vlastníkem se roku 2014 stala společnost Rubik's Brand Ltd.

45 Viz bod 1-5 anotovaného rozhodnutí.

46 Viz bod 6-14 anotovaného rozhodnutí.

47 Viz bod 6, 8 a 10 anotovaného rozhodnutí.
} 
senátu EUIPO zrušil pro nesprávný postup při posouzení toho, zda je dané označení tvořeno výlučně tvarem nebo jinou vlastní výrobku nutných pro dosažení technického výsledku. ${ }^{48}$ Následně první odvolací senát EUIPO vydal rozhodnutí, v němž prohlásil dotčenou známku za neplatnou. Při posuzování výše uvedeného byla pozornost věnována kubickému tvaru Rubikovy kostky, černým liniím i čtverečkům na každé ze stran daného předmětu, jakožto prvkům tvořící dané označení. Všechny tyto prvky přitom byly shledány jakožto nezbytné pro dosažení daného technického výsledku Rubikovy kostky, vč. funkcionality rotace jejích jednotlivých částí. ${ }^{49}$

Posledně uvedené rozhodnutí bylo společností Rubik's Brand Ltd napadeno u Tribunálu. Ten, byt se neztotožnil s př́stupem, který EUIPO zvolil vzhledem $\mathrm{k}$ jednotlivým čtverečkům na stranách Rubikovy kostky (resp. s jejich zohledněním $\mathrm{v}$ daném rozhodnutí), ${ }^{50}$ napadené rozhodnutí potvrdil a žalobu zamítnul. ${ }^{51}$ Uvedl mimo jiné, že černé linie Rubikovy kostky představují fyzické oddělení mezi jednotlivými kostkami, což hráči umožňuje otáčet každou řadu malých kostek nezávisle na sobě, aby tyto malé kostky shromáždil v požadovaném barevném schématu na šesti stranách krychle. Takové fyzické oddělení je nutné $\mathrm{k}$ rotaci, vertikálně a horizontálně. ${ }^{52}$

Daný rozsudek je tak jedním z těch potvrzujících, že institut ochranných známek nemůže bez dalšího vést $\mathrm{k}$ ochraně technických řešení, a to ani u notoricky známých tvarů..$^{53}$

Autor: JS

\footnotetext{
48 Bod 16-19 anotovaného rozhodnutí.

49 Bod 19-30 anotovaného rozhodnutí.

50 Dle bodu 99 anotovaného rozhodnutí tento přístup nikterak neovlivnil závěry rozhodnutí EUIPO.

51 Bod 116 anotovaného rozhodnutí.

52 Bod 86 anotovaného rozhodnutí.

53 Srov. např. rozsudek Soudního dvora Evropské unie ze dne 14. 9. 2010 ve věci C-48/09 P.
} 


\section{AUTORSKÉ PRÁVO}

\section{KONFLIKT MEZI PRÁVY AUTORA A ZÁKLADNÍMI LIDSKÝMI PRÁVY}

Soud: $\quad$ Soudní dvůr Evropské unie

Věc: $\quad$ C-469/17 (Funke Medien NRW)

Datum: 29.7. 2019

Dostupnost: curia.europa.eu

Společnost Funke Medien dne 27. záŕí 2012 požádala o přístup ke všem dokumentům označeným „Unterrichtung des Parlaments“ (,informace pro Parlament“, dále jen „UdP“) vypracovaným v době od 1. zárí 2001 do 26. zář́ 2012. Tyto dokumenty vypracovává každý týden německá vláda. Zprávy UdP jsou považovány za „utajované dokumenty - Vyhrazené“, kdy tato kvalifikace odpovídá nejnižšímu ze čtyř stupňů utajení dle německého práva. Př́slušné orgány žádost společnosti Funke Medien zamítly. Společnost Funke Medien nicméně velkou část UdP získala neznámým způsobem a některé $\mathrm{z}$ těchto zpráv zveřejnila na jejích internetových stránkách $\mathrm{v}$ podobě jednotlivě naskenovaných stránek spolu s úvodní poznámkou, dalšími odkazy a výzvou k diskuzi.

Spolková republika Německo podala proti společnost Funke Medien pro porušení jejích autorských práva $\mathrm{k}$ UdP žalobu na zdržení se jednání, které zemský soud v Kolíně nad Rýnem vyhověl. Odvolání podané společností Funke Medien vrchní zemský soud v Kolíně nad Rýnem zamítl. V rámci opravného prostředku se společnost Funke Medien domáhala zamítnutí žaloby na zdržení se jednání.

Předmětem předběžných otázek je zejména otázka, jakým způsobem má být vykládán čl. 2 písm. a), čl. 3 odst. 1 a čl. 5 odst. 3 písm. c) a d) směrnice $2001 / 29,{ }^{54}$ ve spojení se základními právy, konkrétně svobodou informací a svobodou tisku.

54 Směrnice Evropského parlamentu a Rady 2001/29/ES ze dne 22. května 2001 o harmonizaci určitých aspektů autorského práva a práv s ním souvisejících v informační společnosti. 
Soudní dvưr EU v rámci první předběžné otázky konstatoval, že ustanovení čl. 2 písm. a) a čl. 3 odst. 1 směrnice 2001/29 musí být vykládány $\mathrm{v}$ tom smyslu, že představují opatření úplné harmonizace věcného obsahu práv, která jsou v nich uvedena. ${ }^{55}$ Naproti tomu ustanovení čl. 5 odst. 3 písm. c) druhého případu a písm. d) směrnice 2001/29 dle soudního dvora EU nepředstavují opatření úplné harmonizace rozsahu výjimek či omezení, které jsou v nich obsaženy. ${ }^{56}$ Soudní dvưr EU se dále zabýval druhou a třetí předběžnou otázku, týkající se svobody informací a svobody tisku a jejich kolize s právy autorů. Soudní dvůr konstatoval, že svoboda informací a svoboda tisku nemohou nad rámec zakotvených výjimek a omezení v čl. 5 odst. 3 písm. c) druhého případu a písm. d) směrnice 2001/29 odůvodnit další výjimku z výlučného práva autora. ${ }^{57}$ Vnitrostátní soud musí $\mathrm{v}$ rámci poměřování mezi výlučnými právy autora a právy uživatelů předmětů ochrany vycházet $\mathrm{z}$ výkladu těchto ustanovení, který respektuje jejich znění a zachovává jejich užitečný účinek a zároveň je v úplném souladu se základními právy zaručenými Listinou základních práv EU. ${ }^{58}$

Autorka: DC

\section{VÝJIMKY A OMEZENÍ AUTORSKÉHO PRÁVA V KONTEXTU LIDSKÝCH PRÁV}

Soud: $\quad$ Soudní dvůr Evropské unie

Věc: $\quad$ C-516/17 (Spiegel Online)

Datum: 29. 7. 2019

Dostupnost: curia.europa.eu

Poslanec německého Spolkového sněmu, pan Volker Beck, byl autorem trestněprávního rukopisu. Tento rukopis byl postupem času zveřejněn s úpravami textu a názvu, které pozměnily smysl rukopisu. Při kandidování

\footnotetext{
55 Bod 38 anotovaného rozhodnutí.

56 Bod 40 anotovaného rozhodnutí.

57 Bod 64 anotovaného rozhodnutí.

58 Bod 76 anotovaného rozhodnutí.
} 
do voleb v roce 2013 pan Beck obhajoval své jméno před médii a na důkaz změny smyslu rukopisu tento rukopis uvedeným médiím zpřistupnil. Média, včetně portálu Spiegel Online, bez jeho svolení rukopis bez dalšího zveřejnila. Spiegel Online navíc uvedl, že k žádné změně při dřívějším zveřejnění nedošlo.

Zemský soud v Německu vyhověl žalobě pana Becka na zásah do autorského práva. Po odvolání a po uplatnění dalších opravných prostředků pak Spolkový soudní dvůr tápal při výkladu čl. 5 směrnice InfoSoc v kontextu svobody informací a svobody tisku. Rozhodl se proto vznést předběžnou otázku.

Soudní dvưr byl tázán šesti otázkami na to, zda výjimky a omezení podle čl. 5 směrnice InfoSoc poskytují prostor pro uvážení; jak se zohledňují lidská práva podle Listiny základních práv EU; zda může katalog lidských práv rozšířit taxativní výčet výjimek a omezení či jaké jsou náležitosti zveřejnění pro účely citace. ${ }^{59}$

Soudní dvưr vyložil možnosti prostoru pro uvážení při aplikaci unijních norem $\mathrm{s}$ ohledem na charakter harmonizace, ${ }^{60}$ která $\mathrm{v}$ tomto případě není plná. ${ }^{61}$ Stejně tak apeloval na podstatu lidských práv zakotvených v Listině základních práv Evropské unie. ${ }^{62}$ Soudní dvưr dále připomněl, že katalog výjimek a omezení v dané směrnici je taxativní, ${ }^{63}$ což je plně v souladu s tradicemi a zaručenými lidskými právy. ${ }^{64}$ Výklad jednotlivých výjimek a omezení přitom musí být plně $v$ souladu s šetřením právě těchto práv. ${ }^{65}$ $\mathrm{Na}$ adresu citace Soudní dvůr uvedl zejména její význam ${ }^{66}$ a roli $\mathrm{v}$ informační společnosti v kontextu internetu. ${ }^{67} \mathrm{~V}$ závěru pak Soudní dvůr

\footnotetext{
59 Srov. bod 15 anotovaného rozhodnutí.

60 Srov. bod 18 anotovaného rozhodnutí.

${ }^{61}$ Srov. body 26 a násl. anotovaného rozhodnutí.

62 Srov. bod 20 anotovaného rozhodnutí.

63 Srov. bod 41 anotovaného rozhodnutí.

64 Srov. body 42 a násl. anotovaného rozhodnutí.

65 Srov. body 52 a násl. anotovaného rozhodnutí.

66 Srov. bod 78 anotovaného rozhodnutí.

67 Srov. bod 81 anotovaného rozhodnutí.
} 
uvedl, že podmínka vázanosti zpřístupnění díla veřejnosti na souhlas autora by byla př́liš̌ restriktivní. ${ }^{68}$

Soudní dvůr uzavřel, že čl. 5 směrnice InfoSoc nepředstavuje opatření plné harmonizace. Dále dodal, že svoboda informací ani svoboda tisku nemohou založit další výjimku či omezení, které by nebyly v katalogu této směrnice. Na druhou stranu však výklad již existujících výjimek a omezení musí respektovat lidská práva dle Listiny základních práv Evropské unie. Co do citace, Soudní dvůr uvedl, že i hypertextový odkaz může být citací, a že zpřístupnění veřejnosti není nutně podmíněno souhlasem autora.

Autor: JZ

\section{METALL AUF METALL}

Soud: $\quad$ Soudní dvůr Evropské unie

Spojené věci: C-476/17 (Pelham)

Datum: 29. 7. 2019

Dostupnost: curia.europa.eu

Společnost Pelham pořídila zvukový záznam skladby Nur mir, která údajně obsahovala dvouvteřinový vzorek (sample) rytmické sekvence dřive zveřejněné skladby Metall auf Metall.

Výrobci záznamu skladby Metall auf Metall žalovali společnost Pelham pro porušení práv výrobce zvukového záznamu, jakož i práv výkonných umělců a práv autorských k dané skladbě. Zemský dvơr v Hamburku žalobě vyhověl. Odvolání společnosti Pelham pak bylo opakovaně zamítnuto, až se věc dostala ke Spolkovému ústavnímu soudu, který věc vrátil ke Spolkovému soudnímu dvoru a ten pro nejednotnou judikaturu předložil Soudnímu dvoru předběžné otázky.

Soudní dvơr měl zodpovědět, zda vynětí velmi krátkých zvukových úryvků může být zásahem do práva výrobce zvukových záznamů, zda se v takovém případě jedná o rozmnoženinu, či zda je takový akt krytý některou z výjimek a omezení. Soudní dvơr byl navíc tázán, jaká je v dané

${ }^{68}$ Srov. body 89 a násl. anotovaného rozhodnutí. 
situaci aplikovatelnost citační výjimky, zda existuje alespoň minimální prostor pro uvážení při provádění výjimek a omezení a jaká je $\mathrm{v}$ daném kontextu role základních lidských práv.

Soudní dvůr připomněl rozsah práv výrobců zvukových záznamů ${ }^{69}$ a stejně tak apeloval na nutný soulad a rovnováhu se základními lidskými právy katalogovanými $\mathrm{v}$ Listině základních práv Evropské unie. ${ }^{70} \mathrm{Na}$ základě toho uvedl, že samplování nemůže být chápáno jako rozmnožování ve smyslu čl. 2 směrnice InfoSoc. ${ }^{71}$ Soudní dvůr dále vyzdvihnul nutnou návratnost investice do výroby zvukových záznamů a důležitost práva výrobce, jakož i nutnost boje proti pirátství a s tím spojenou analýzu dopadu ochrany rozmnoženin. ${ }^{72}$ Soudní dvůr též vyložil tzv. právo na volné užitit $^{73}$ a zdůraznil roli lidských práv při aplikaci základních výjimek a omezení. ${ }^{74} \mathrm{Na}$ adresu citace Soudní dvůr dodal, že citace se může týkat i hudebního díla, ${ }^{75}$ bude záležet na kontextu užití takové citace, rozeznatelnosti v těle další skladby a obvyklém smyslu. ${ }^{76}$

Soudní dvůr proto uzavřel, že výrobce zvukových záznamů může bránit tomu, aby třetí osoba použila byt jen velmi krátký zvukový vzorek z onoho záznamu a začlenila ho do jiného zvukového záznamu, ledaže je do něj tento vzorek začleněn $\mathrm{v}$ pozměněné a při poslechu nerozpoznatelné podobě. Stejně tak uvedl, že záznam obsahující přenesené hudební vzorky není rozmnoženinou jako takovou, protože nepřebírá prvotní záznam nebo jeho podstatnou část. Dodal dále, že výčet výjimek a omezení dle čl. 5 směrnice InfoSoc je taxativní, pro použití citační výjimky musí být dílo, které je předmětem dotčené citace, rozeznatelné. Uzavřel, že čl. 2 této směrnice představuje opatření plné harmonizace.

Autor: JZ

\footnotetext{
69 Srov. body 26 a násl. anotovaného rozhodnutí.

70 Srov. body 32 a násl. anotovaného rozhodnutí.

71 Srov. bod 37 anotovaného rozhodnutí.

72 Srov. body 44 a násl. anotovaného rozhodnutí.

73 Srov. bod 56 anotovaného rozhodnutí.

74 Srov. body 60 a násl. anotovaného rozhodnutí.

75 Srov. bod 68 anotovaného rozhodnutí.

76 Srov. body 70 a násl. anotovaného rozhodnutí.
} 


\section{ZÁKON REGULUJÍCÍ ČINNOST VYHLEDÁVAČE JE „TECHNICKÝ PŘEDPIS“ VE SMYSLU SMĚRNICE 98/34}

Soud: $\quad$ Soudní dvůr Evropské unie

Věc: $\quad$ C-299/17 (VG Media)

Datum: $\quad$ 12. 9. 2019

Dostupnost: curia.europa.eu

Při zadání vyhledávaného výrazu do vyhledavače provazovaného společností Google se zobrazí tzv. Snippet, což je krátký text nebo úryvek textu sloužící uživateli k posouzení relevantnosti zobrazeného výsledku pro jeho konkrétní potřebu. Společnost VG Media podala proti společnosti Google žalobu na náhradu škody způsobenou tím, že společnost Google od 1. 8. 2013 používá při zobrazení výsledků vyhledávání zpráv úryvky z textů, obrázky a pohyblivé obrázky, aniž za to platí poplatek. Tento závěr společnost VG Media dovodila z ustanovení autorského zákona, která Snippety regulují a která nabyla účinnosti právě 1. 8. 2013.

Soudní dvưr byl tázán, zda čl. 1 bod 11 směrnice 98/34 (o postupu při poskytování informací v oblasti norem a technických předpisů a předpisů pro služby informační společnosti) musí být vykládán $v$ tom smyslu, že vnitrostátní ustanovení, které zakazuje pouze komerčním provozovatelům vyhledávačů a komerčním poskytovatelům služeb, kteří zpracovávají obsah obdobným způsobem, veřejně zpřístupňovat tiskoviny nebo jejich části (s výjimkou jednotlivých slov nebo velmi krátkých úryvků textu), představuje „technický předpis“, jehož návrh musí být pod rizikem sankce neaplikovatelnosti předem oznámen Komisi. ${ }^{77}$

Soudní dvưr v této souvislosti uvedl, že technický předpis představuje čtyři kategorie opatření, a to zaprvé technickou specifikaci, zadruhé jiný požadavek, zatřetí předpis pro služby nebo začtvrté právní a správní předpisy členských států zakazující výrobu, dovoz, prodej nebo používání určitého výrobku nebo zakazující poskytování nebo využívání určité služby

77 Srov. bod 24 anotovaného rozhodnutí. 
nebo usazování poskytovatele služeb. ${ }^{78}$ Předmětné vnitrostátní ustanovení nelze považovat za technickou specifikaci, nebot’ se nevztahuje na výrobek nebo jeho obal, ${ }^{79}$ nespadá ani do kategorie jiný požadavek, nebot? se netýká spotřebního cyklu výrobku po jeho uvedení na trh. ${ }^{80}$

Aby byl technický předpis považován za předpis pro služby, musí být zaměřený specificky na služby informační společnosti. ${ }^{81}$ Soudní dvůr konstatoval, že ačkoli tento cíl nevyplývá ze samotného znění vnitrostátního ustanovení, z jeho odůvodnění vyplývá, že jeho konkrétním záměrem je výslovně a cíleně regulovat služby informační společnosti a chránit oprávněné zájmy vydavatelů tisku před porušováním autorského práva prostřednictvím vyhledávačů on-line. ${ }^{82}$

Soudní dvưr tedy dospěl k závěru, že předmětné ustanovení představuje technický předpis a jeho návrh tak musí být $\mathrm{v}$ souladu s požadavkem vyplývajícím ze směrnice 98/34 předem oznámen Komisi.

Autorka: IK

\section{OCHRANA DESIGNU AUTORSKÝM PRÁVEM}

Soud: $\quad$ Soudní dvůr Evropské unie

Spojené věci: C-683/17 (Cofemel)

Datum: $\quad$ 12. 9. 2019

Dostupnost: curia.europa.eu

Společnost Cofemel navrhovala a vyráběla oděvy stejně jako společnost $G$ Star, která je držitelem několika ochranných známek užívaných v oděvním průmyslu, konkrétně v případě džín, mikin a triček. Společnost Cofemel se přitom měla dopustit užívání designu chráněného ochrannými známkami bez náležité licence.

\footnotetext{
78 Srov. bod 25 anotovaného rozhodnutí.

79 Srov. bod 26 anotovaného rozhodnutí.

80 Srov. tamtéž.

81 Srov. bod 31 anotovaného rozhodnutí.

${ }^{82}$ Srov. bod 35 a 36 anotovaného rozhodnutí.
} 
Společnost G-Star podala proti uvedené společnosti Cofemel žalobu pro porušování autorských práv a nekalosoutěžní jednání, přičemž tvrdila, že jednotlivé modely oblečení jsou jejími autorskými díly. Právě tuto argumentaci společnost Cofemel rozporovala. Soud prvního stupně žalobě částečně vyhověl. Po odvolání společnosti Cofemel soud druhého stupně daný rozsudek potvrdil. V návaznosti na podané dovolání Nejvyšší soud Portugalska provedl výklad pojmových znaků autorského díla a pro nejasnou judikaturu položil Soudnímu dvoru předběžné otázky.

Soudní dvůr musel řešit, zda je originalita nutným pojmovým znakem i v př́padě děl užitého umění, průmyslových vzorů a designových děl, která mají vedle užitného účelu vlastní charakteristický vizuální efekt z estetického hlediska. Stejně tak měl posoudit, zda naplnění znaku uměleckého výtvoru není pro dosažení autorskoprávní ochrany díla postačující.

Soudní dvůr odkázal na svou bohatou judikaturu v oblasti pojmových znaků autorského díla ${ }^{83}$ a připomněl podstatnou roli originality, která musí odrážet osobnost autora v mezích tvůrčí svobody, ${ }^{84}$ jakož i roli objektivního zachycení. ${ }^{85}$ Jedině při naplnění všech těchto Soudním dvorem dovozených znaků bude daná komodita dílem a bude chráněna autorským právem. Po odkazu na Bernskou úmluvu ${ }^{86}$ Soudní dvůr zdůraznil souběh ochrany průmyslových vzorů a autorského práva $^{87}$ a připomněl zejména jejich odlišný charakter, cíl a odlišné režimy ochrany. ${ }^{88}$ Po takovém rozboru Soudní dvůr naznal, že je bezpředmětné zodpovídat druhou položenou otázku.

Soudní dvưr dospěl k závěru, že autorskoprávní ochrana nemůže být přiznávána průmyslovým vzorům jen proto, že mají vedle vlastního užitného účelu i charakteristický vizuální efekt z hlediska estetického.

Autor: JZ

\footnotetext{
83 Srov. body 28 a násl. anotovaného rozhodnutí.

84 Srov. bod 30 anotovaného rozhodnutí.

85 Srov. bod 32 anotovaného rozhodnutí.

86 Srov. body 41 a násl. anotovaného rozhodnutí.

87 Srov. body 45 a 48 anotovaného rozhodnutí.

88 Srov. body 50 a násl. anotovaného rozhodnutí.
} 


\section{OSOBNÍ ÚDAJE A SOUKROMÍ}

\section{MOŽNOST TRESTAT PORUŠENÍ NAŘÍZENÍ 2016/679 V ŘÍZENÍ ZAHÁJENÝCH PŘED PŘIJETÍM ADAPTAČNÍ LEGISLATIVY}

Soud:

Nejvyšší správní soud

Věc:

9 As 380/2017 - 46

Datum:

31. 1. 2019

Dostupnost: nssoud.cz

Stavební bytové družstvo Praha se dopustilo neoprávněného shromažd’ování osobních údajů vlastníků, nájemců, podnájemců a dalších členů domácnosti všech bytových a nebytových jednotek, které jsou v jeho vlastnictví či správě. ${ }^{89}$

$\mathrm{V}$ roce $2016 \mathrm{mu}$ byla za tento správní delikt podle zákona o ochraně osobních údajự ${ }^{90}$ uložena pokuta Úřadem pro ochranu osobních údajů. Družstvo proti rozhodnutí podalo rozklad, jenž předsedkyně Úřadu zamítla. Věc dále pokračovala k Městskému soudu v Praze, jenž v roce 2017 žalobu proti rozhodnutí zamítl jako nedo̊vodnou. Tento rozsudek proto družstvo napadlo kasační stížností u Nejvyššího správního soudu, který ji rovněž shledal nedůvodnou a zamítl ji in fine. ${ }^{91}$

V průběhu řízení před Nejvyšším správním soudem družstvo namítalo, že dne 25. 5. 2018 účinnost nařízení 2016/679. Zákon o ochraně osobních údajů sice nebyl formálně zrušen, avšak účinností nařízení 2016/679 došlo k faktické derogaci hmotněprávních norem tohoto zákona a jejich nahrazení přímo aplikovatelným nařízením. Současně však tehdy ještě nebyl přijat adaptační zákon $\mathrm{k}$ jeho provedení.

Vzhledem k těmto skutečnostem, bylo družstvo toho názoru, že trestnost jeho jednání dnem účinnosti nařízení 2016/679 zanikla, jelikož se trestnost jeho činu posoudí a trest ukládá podle právní úpravy, která nabyla

\footnotetext{
89 Bod 9 anotovaného rozhodnutí.

90 Zákon č. 101/2000 Sb., o ochraně osobních údajů a o změně některých zákonů.

91 Bod 1, 3, 11 a 57 anotovaného rozhodnutí.
} 
účinnosti až poté, kdy byl trestný čin spáchán, je-li to pro pachatele příznivější. Opíral se přitom o názor, že nařízení 2016/679 nemůže formulovat univerzální skutkové podstaty deliktních jednání a přímo na jeho základě není možné trestat. ${ }^{92}$ Nejvyšší správní soud se proto zabýval otázkou, zda není nutné na odpovědnost stěžovatele aplikovat novou právní úpravu nařízení 2016/679, přičemž na základě usneseníč. j. 5 As 104/2013 - 46 došel k tomu, že novou, pro pachatele příznivější úpravu lze použít pouze ve správním řízení, případně v řízení před krajským (zde městským) soudem. Soud se proto již dále nezabýval ani otázkou, zda by úprava byla pro pachatele skutečně př́iznivější. ${ }^{93}$

Z tohoto závěru vyplývá, že nařízení 2016/679 skutečně představuje „komplexní podklad pro ukládání sankcí“, jak jej nazval Úřad ${ }^{94}$ a bylo by podle něj možné trestat porušení nových povinností, které by nebylo možné postihnout podle zákona o ochraně osobních údajů. Přijetím zákona o zpracování osobních údajü ${ }^{95}$ byla však tato mezera v právní úpravě již překlenuta.

Autorka: AS

\section{PŘECHOD OD ZÁKONA 101/2000 SB. K OBECNÉMU NAŘÍZENÍ}

Soud: $\quad$ Nejvy̌ší správní soud

Věc: $\quad 4$ As $140 / 2019-27$

Datum: 27.6. 2019

Dostupnost: nssoud.cz

Ministerstvo vnitra (MV) od záŕí 2014 do října 2014 umožnilo chybným nastavením informačního sytému neoprávněný přístup České televizi a Českému rozhlasu do Registru obyvatel, čímž došlo k porušení zabezpečení osobních údajů dohromady v přibližně 70250 případech. ${ }^{96}$

\footnotetext{
92 Bod 19 anotovaného rozhodnutí.

93 Bod 56 anotovaného rozhodnutí.

94 Bod 27 anotovaného rozhodnutí.

95 Zákon č. 110/2019 Sb., o zpracování osobních údajů.

96 Odst. 3 anotovaného rozhodnutí.
} 
Úřad pro ochranu osobních údajů (ÚOOÚ) proto uložil MV pokutu v celkové výši 500000 Kč. MV podalo správní žalobu a po potvrzení rozhodnutí ÚOOÚ rovněž kasační stížnost. MV svoji stížnost podložilo řadou argumentů, z nichž nejzajímavější je ten, dle kterého Obecné nařízení o ochraně osobních údajů (nařízení č. 2016/679, dále GDPR) klade na správce osobních údajů mírnější nároky než zákon č. 101/2000 Sb. (dále ZoOOÚ), protože jeho čl. 24 a 32 stanoví povinnosti pro správce mírněji, než rigidní $\S 13$ ZoOOÚ. Vzhledem $\mathrm{k}$ tomu měl dle názoru MV ÚOOÚ i Městský soud v Praze přihlédnout $\mathrm{k}$ této mírnější úpravě a pokutu neudělit, nebo zrušit.

Hlavní řešenou otázkou je v tomto př́padě vztah $\S 13$ odst. 1 ZoOOÚ a čl. 24 a 32 GDPR.

MV uvádí, že zatímco $\S 13$ odst. 1 ZoOOÚ klade na správce údajů v podstatě absolutní nároky bez výjimky, nové čl. 24 a 32 GDPR požadují pouze „vhodná opatření“, případně „vhodnou úroveň bezpečnosti“, přičemž má být zhodnocena hlavně rizikovost daného zpracování. ${ }^{97} \mathrm{Z}$ toho důvodu je dle MV nová úprava pro správce příznivější.

NSS odmítl argumentaci MV a kasační stížnost zamítl. Dle NSS není možné vykládat ustanovení GDPR jako příznivější právní úpravu. Rozdíl mezi $\S 13$ odst. 1 ZoOOÚ a čl. 24 a 32 GDPR není možné vykládat tak, že $\S 13$ odst. 1 představuje absolutistický požadavek na zabezpečení, zatímco čl. 24 a 32 GDPR tento požadavek neobsahují. Dle NSS čl. 24 a 32 pouze výslovně konkretizují hlediska, knimž správce musel přihlížet i při posuzovaní opatření dle $\S 13$ odst. 1 ZoOOÚ. ${ }^{98} \mathrm{Z}$ argumentace stěžovatelky pak dle NSS nevyplynulo, že by její jednání nepředstavovalo správní delikt dle GDPR. ${ }^{99}$ Neobstál ani argument MV, že riziko zpracování bylo nízké, protože neoprávněný přístup $\mathrm{k}$ údajům měly jen Česká televize a Český rozhlas. $^{100}$ NSS odmítl bagatelizaci vytýkaného porušení zabezpečení

\footnotetext{
97 Odst. 9 anotovaného rozhodnutí.

98 Odst. 26 anotovaného rozhodnutí.

99 Odst. 28 anotovaného rozhodnutí.

100 Odst. 12 anotovaného rozhodnutí.
} 
a připomněl, že Česká republika je ústavně definována jako právní stát, a proto je nutné vyžadovat důsledné respektování zákonných povinností. ${ }^{101}$

Autor: JM

\section{TLAČÍTKO „TO SE MI LÍBÍ“ A S NÍM SOUVISEJÍCÍ ROLE SPRÁVCŮ OSOBNÍCH ÚDAJŮ}

Soud: $\quad$ Soudní dvůr Evropské unie

Věc: $\quad$ C-40/17 (Fashion ID)

Datum: $\quad$ 29. 7. 2019

Dostupnost: curia.europa.eu

Rozsudek Soudního dvora byl vydán na základě několika předběžných otázek, které tomuto byly předloženy $\mathrm{v}$ rámci sporu mezi společností Fashion ID GmnH \& Co KG („Fashion ID“) a Verbraucherzentrale NRW eV ohledně začlenění pluginu pro propojení se sociální sítí Facebook. Ten společnost Fashion ID použila na svých webových stránkách. ${ }^{102}$ Fashion ID do svých webových stránek konkrétně začlenila tlačítko „to se mi líbí“. ${ }^{103}$ Na základě tohoto přitom měly být osobní údaje návštěvníků stránek Fashion ID předány společnosti Facebook Ireland Ltd. ${ }^{104}$ Verbraucherzentrale NRW $\mathrm{eV}$ jakožto veřejně prospěšné sdružení na ochranu zájmů spotřebitelů podalo žalobu proti společnosti Fashion ID, aby ukončila svou praxi spočívající $\mathrm{v}$ onom předávání osobních údajů bez souhlasu subjektů údajů a za porušení informační povinnosti vůči těmto subjektům. ${ }^{105}$ Zemský soud v Düsseldorfu této žalobě částečně vyhověl a společnost Fashion ID se proti danému rozhodnutí následně odvolala. ${ }^{106}$

\footnotetext{
${ }^{101}$ Odst. 33 anotovaného rozhodnutí.

102 Bod 2 anotovaného rozhodnutí.

${ }^{103}$ Bod 25 anotovaného rozhodnutí.

104 Bod 27 anotovaného rozhodnutí.

105 Bod 28 a 29 anotovaného rozhodnutí.

${ }^{106}$ Bod 30 a 31 anotovaného rozhodnutí.
} 
Odvolacím soudem je v dané věci vrchní zemský soud v Düsseldorfu, který je rovněž předkladatelem předběžných otázek. ${ }^{107}$

V rámci odpovědí došel Soudní dvůr k tomu, že články 22 až 24 směrnice 95/96 nebrání vnitrostátní právní úpravě umožňující sdružením na ochranu spotřebitelů podat žalobu proti údajnému rušiteli ochrany osobních údajů. ${ }^{108}$

Soudní dvůr $\mathrm{v}$ rámci odpovědí na předběžné otázky konstatoval, že Fashion ID je možné (stejně jako druhou ze zmíněných společností) považovat za správce osobních údajů sbíraných a následně předávaných společnosti Facebook Ireland Ltd. ${ }^{109}$ To proto, že společně s Facebook Ireland Ltd. určuje účel a prostředky zpracování osobních údajů. ${ }^{110}$ Výše uvedené Soudní dvůr dovodil i přesto, že k těmto osobním údajům Fashion ID nemá přístup. ${ }^{111}$

Následně Soudní dvůr mimo jiné konstatoval, že povinnost získání souhlasu v dané věci, stejně jako výkon informační povinnosti, leží na prvním ze správců, tedy Fashion ID, avšak logicky pouze pro operace nebo soubory operací, u nichž skutečně určuje účely a prostředky zpracování. ${ }^{112}$

Anotované rozhodnutí vnáší větší jistotu do vztahů mezi provozovateli internetových stránek a poskytovateli služeb využívající tlačítka typu „to se mi líbí“, a to nejen ve smyslu již zrušené směrnice 95/46/ES, ale i ve smyslu v současné době účinného nařízení (EU) 2016/279. Závěry $\mathrm{z}$ anotovaného rozhodnutí jsou totiž obecně aplikovatelné i při výkladu jeho ustanovení.

Autor: JS

\footnotetext{
107 Bod 31 anotovaného rozhodnutí.

${ }^{108}$ Bod 43 až 63 anotovaného rozhodnutí.

109 Bod 85 anotovaného rozhodnutí.

${ }^{110}$ Viz bod 65-71 anotovaného rozhodnutí. V souvislosti s tímto je vhodné upozornit na zakotvení institutu společného správcovství v čl. 26 nařízení (EU) 2016/279, které směrnici 95/46/ES zrušilo. To však neznamená, že by závěry z anotovaného rozhodnutí nebyly použitelné i dle současné právní úpravy.

111 Bod 82 anotovaného rozhodnutí.

${ }^{112}$ Bod 98-106 anotovaného rozhodnutí.
} 


\title{
POVINNOST PROVOZOVATELE VYHLEDÁVAČE ODSTRANIT ODKAZY VEDOUCÍ KE ZVLÁŠTNÍM KATEGORIÍM OSOBNÍCH ÚDAJŮ Z VÝSLEDKŮ VYHLEDÁVÁNí
}

\author{
Soud: $\quad$ Soudní dvůr Evropské unie \\ Věc: $\quad$ C-136/17 (GC a další) \\ Datum: $\quad$ 24. 9. 2019 \\ Dostupnost: curia.europa.eu
}

Předmětem sporu v původním řízení byly na sobě nezávislé žádosti subjektů údajů GC, AF, BH a ED o výmaz odkazů z výsledků vyhledávání, které se ve vyhledávači společnosti Google zobrazily po zadání jejich jmen. Od politických názorů přes náboženská přesvědčení až po údaje týkající se protiprávního jednání - ve všech případech se jednalo o odkazy vedoucí ke zvláštním kategoriím údajů. ${ }^{113}$

Poté, co společnost Google odmítla těmto žádostem o výmaz vyhovět, se subjekty údajů obrátily na CNIL (francouzský dozorový úřad), který však řízení o stížnostech zastavil. Stěžovatelé proto podali žaloby ke Conseil d'État (Státní rada), která je spojila a dospěla k závěru, že v rámci argumentace vyvstalo několik problematických otázek, které je nutné adresovat Soudnímu dvoru. ${ }^{114}$

Tyto otázky se týkaly výkladu čl. 8 směrnice o ochraně osobních údajů $^{115}$, jakož i čl. 9 a 10 nařízení 2016/679 $9^{116}$, konkrétně rozsahu povinností provozovatele vyhledávače jako správce osobních údajů respektovat zákaz zpracování zvláštních kategorií osobních údajů, jsou-li takové údaje součástí obsahu umístěném na internetu třetími osobami,

\footnotetext{
113 Bod 25-28 anotovaného rozhodnutí.

114 Bod 29-31 anotovaného rozhodnutí.

${ }^{115}$ Směrnice Evropského parlamentu a Rady 95/46/ES ze dne 24. října 1995 o ochraně fyzických osob v souvislosti se zpracováním osobních údajů a o volném pohybu těchto údajů.

${ }^{116}$ Nařízení Evropského parlamentu a Rady (EU) 2016/679 ze dne 27. dubna 2016 o ochraně fyzických osob v souvislosti se zpracováním osobních údajů a o volném pohybu těchto údajů a o zrušení směrnice 95/46/ES (obecné nařízení o ochraně osobních údajů).
} 
a umožnit výkon práva subjektu údajů na výmaz při vyvážení s ostatními základními právy, zejm. svobodou informací.

V rozsudku Soudní dvůr navazuje na své závěry z věci Google Spain ${ }^{117}$ $a$ dodává, že s přihlédnutím ke zvláštnostem zpracování vyhledávače se jeho provozovatel jakožto správce musí řídit zákazem zpracování zvláštních kategorií údajů, a to když tento provozovatel pod dohledem příslušných vnitrostátních orgánů provádí ověření na základě žádosti subjektu údajů. ${ }^{118}$ Provozovatel vyhledávače je přitom na základě těchto ustanovení povinen až na stanovené výjimky vyhovět žádostem o odstranění odkazů na internetové stránky, které obsahují zvláštní kategorie osobních údajů. $\mathrm{V}$ případě, kdy je některá $\mathrm{z}$ výjimek aplikovatelná, provozovatel musí vyvážit základní práva na základě všech relevantních okolností věci a s ohledem na závažnost zásahu do základního práva subjektu údajů na soukromí a na ochranu osobních údajů ověřit, zda je uvedení tohoto odkazu nezbytně nutné $\mathrm{k}$ tomu, aby bylo chráněno právo uživatelů internetu na svobodu informací. ${ }^{119} \mathrm{~V}$ případě zpracování zvláštní kategorie údajů týkajících se protiprávního jednání či rozsudků v trestních věcech, provozovatel vyhledávače je povinen vyvážit základní práva a zpravidla vyhovět žádosti o odstranění odkazů, pokud se informace týkají dřívější fáze dotčeného soudního řízení, již neodpovídající současnému stavu.

Ač Soudní dvůr potvrdil obecný zákaz zpracování zvláštních kategorií údajů, rozhodnutí ve svém důsledku zohledňuje zvláštní povahu zpracování prováděném provozovatelem vyhledávače a přibližuje za těchto okolností výkon práva na výmaz institutu notice-and-action, čímž zároveň dochází $\mathrm{k}$ přenosu větší odpovědnost za vyvažování základních práv na samotné povinné subjekty.

Autorka: AS

\footnotetext{
${ }^{117}$ Rozsudek Soudního dvora (velkého senátu) ze dne 13. května 2014, ve věci C 131/12 Google Spain SL, Google Inc. proti Agencia Española de Protección de Datos (AEPD), Mario Costeja González.

118 Bod 45-48 anotovaného rozhodnutí.

${ }^{119}$ Bod 69 anotovaného rozhodnutí.
} 


\section{TERITORIÁLNA PÔSOBNOSŤ PRÁVA „NA ZABUDNUTIE“}

Soud: $\quad$ Súdny dvor Europskéj Únie

Věc: $\quad$ C-507/17 (Google v CNIL)

Datum: $\quad 24.9 .2019$

Dostupnost: curia.europa.eu

Francúzsky úrad na ochranu osobných údajov CNIL vydal voči spoločnosti Google rozhodnutie, v ktorom nariadil Google odstránit zo svojho vyhl'adávača odkazy vedúce na webové stránky, ktoré sa zobrazili ako výsledky vyhladávania mena dotknutej osoby, pričom toto odstránenie odkazov malo byt vykonané na všetkých koncovkách doménového mena vyhladávača. Google tejto výzve odmietol vyhoviet a odstránil predmetné odkazy iba z výsledkov zobrazených vo verziách svojho vyhl’adávača, ktoré mali doménové meno členského štátu EÚ. CNIL mu na základe neuposlúchnutia výzvy uložil pokutu 100000 EUR. ${ }^{120}$

Google podal proti rozhodnutiu, ktorým mu CNIL uložil pokutu, žalobu na francúzsky súd. Ten inicioval konanie o predbežnej otázke pred SDEÚ. ${ }^{121}$

Hlavnou predbežnou otázkou posudzovanou SDEÚ bolo, či má poskytovatel' vyhl'adávača $\mathrm{v}$ prípade, ak vyhovie žiadosti dotknutej osoby o odstránenie odkazov, vykonat toto odstránenie na všetkých doménach svojho vyhladávača a $\mathrm{v}$ prípade, že nie, $\mathrm{z}$ ktorých verzií domén má toto odstránenie vykonat. Súd zároveň riešil aj povinnost̉ vyhladávačov v týchto prípadoch využit tzv. geoblokáciu. ${ }^{122}$

SDEÚ vychádzal zo svojho predchádzajúceho rozhodnutia vo veci Google Spain, ${ }^{123}$ pričom podobne ako v tomto prípade vykladal článok $12 \mathrm{~b}$ ) a článok 14 a) smernice o ochrane osobných údajov, ${ }^{124}$ avšak do výkladu

\footnotetext{
${ }^{120}$ Body 30-33 anotovaného rozhodnutia.

${ }^{121}$ Bod 39 anotovaného rozhodnutia.

122 Tamtiež.

${ }^{123}$ Rozsudok SDEÚ vo veci C-131/12 z 13. mája 2014, Google Spain a Google (d’alej len „Google Spain“).

${ }^{124}$ Smernica Európskeho parlamentu a Rady 95/46/EHS z 24. októbra 1995 o ochrane fyzických osôb pri spracovaní osobných údajov a vol’nom pohybe týchto údajov.
} 
začlenil aj článok 17 ods. 1 GDPR. ${ }^{125}$ Podl’a SDEÚ treba právo na zabudnutie, ktoré nie je absolútnym právom, vyvažovat aj s inými právami, najmä s právom na informácie. Nakol'ko rôzne štáty sveta majú rôzny prístup k vyváženiu týchto práv prípadne právo na zabudnutie ani nepoznajú a nakol'ko zákonodarca v predmetných predpisoch nepredpokladal, že by právo na zabudnutie malo mat pôsobnost̉ mimo EÚ, poskytovatel' vyhladávača nie je povinný vykonat’ odstránenie odkazu vo všetkých verziách vyhl'adávača. ${ }^{126} \mathrm{Ak}$ však vyhovie žiadosti o odstránenie odkazu, je povinný ho odstránit’ vo verziách vyhl'adávača zodpovedajúcich všetkým členským štátom, vzhl'adom na skutočnost’, že právo byt zabudnutý je upravené v GDPR ako v norme s priamou pôsobnostou v celej EÚ. ${ }^{127}$ Zároveň je vyhl'adávač v prípade potreby povinný vykonat̉ opatrenia, ktoré sú v súlade so zákonom a ktoré zabránia používatel’om z EÚ (resp. ich účinne odradia) pristúpit’ k odstráneným odkazom cez doménu vyhl'adávača určenú pre používatel’ov z iného ako členského štátu EÚ. ${ }^{128}$

Rozsudok bližšie upresňuje teritoriálnú pôsobnost̉ právo na zabudnutie a obmedzuje tak právo fyzických osôb z členských štátov EÚ požadovat globálne odstránenie odkazu vo výsledkoch vyhladávania zobrazených po vyhladaní ich mena.

Autorka: PV

\section{PŘEDZAŠKRTNUTÉ POLÍČKO NENÍ PLATNÉ VYJÁDŘENÍ SOUHLASU}

Soud: $\quad$ Soudní dvůr Evropské unie

Věc: $\quad$ C-673/17 (Planet49)

Datum: $\quad$ 1. 10. 2019

Dostupnost: curia.europa.eu

\footnotetext{
${ }^{125}$ Nariadenie Európskeho parlamentu a Rady (EÚ) 2016/679 z 27. apríla 2016 o ochrane fyzických osôb pri spracúvaní osobných údajov a o vol’nom pohybe takýchto údajov, ktorým sa zrušuje smernica 95/46/ES (všeobecné nariadenie o ochrane údajov).

${ }^{126}$ Body 59-65 anotovaného rozhodnutia.

${ }^{127}$ Bod 66 anotovaného rozhodnutia.

${ }^{128}$ Bod 70 anotovaného rozhodnutia.
} 
Německá společnost žalovala Planet 49 , za používání předzaškrtnutého políčka pro souhlas s používáním cookies a následné předávání údajů třetím stranám. ${ }^{129}$ Zemský soud žalobě částečně vyhověl, načež vyšší zemský soud rozhodl opačně. ${ }^{130}$ Až Spolkový soudní dvưr podal předběžné otázky SDEU, kterých se ptal, zda je je předzaškrtnuté políčko platným souhlasem dle čl. 5 odst. 3 směrnice 2002/58/ES, zda při použití čl. 5 odst. 3 směrnice 2002/58/ES hraje roli, pokud jsou zpracované informace osobními údaji a jaké informace musí poskytovatel služby podle čl. 5. odst. 3 směrnice 2002/58/ES poskytnout. ${ }^{131}$

Spor bylo nutné posoudit dle původní i nové legislativy. ${ }^{132}$ SDEU se zabýval vývojem čl. 5 odst. 3 směrnice 2002/58/ES, jež původně požadoval pro ukládání souborů do koncových zařízení možnost takové ukládání odmítnout (opt-out) a po novelizaci byl zpřísněn požadavek na explicitní souhlas (opt-in). ${ }^{133}$ Novelizace $\mathrm{v}$ německém právním řádu však zvýšený nárok nereflektovala a ponechala režim opt-out. ${ }^{134}$

Pokud souhlas uživatele spočívá $\mathrm{v}$ absenci vyjádření námitky proti předzaškrtnutému políčku, pak dle SDEU nelze s jistotou říci, zda bude uživatel př̀d-zaškrtnutému poličku věnovat pozornost. Nečinnost ani nedbalost proto dostatečně nevypovídá o vůli uživatele. ${ }^{135}$ SDEU konstatoval, že pro platný souhlas, musí být uživatel schopný posoudit vlastní situaci natolik, aby znal efekt udělení souhlasu. ${ }^{136} \mathrm{~K}$ tomuto rozhodnutí je nezbytné mít kvalitní a dostupné informace, jakými je: doba funkčnosti cookies a možnost přístupu třetích osob. ${ }^{137}$

\footnotetext{
${ }^{129}$ Bod 24 anotovaného rozhodnutí.

${ }^{130}$ Bod 30-31 anotovaného rozhodnutí.

${ }^{131}$ Bod 32 anotovaného rozhodnutí.

132 Bod 49 anotovaného rozhodnutí.

133 Bod 54 anotovaného rozhodnutí.

${ }^{134}$ Stejně jako v českém $§ 89$ odst. 3 zákona o elektronických komunikacích č. 127/2005 Sb.

135 Bod 62 anotovaného rozhodnutí.

${ }^{136}$ Bod 67 anotovaného rozhodnutí.

137 Body 117-120 anotovaného rozhodnutí.
} 
SDEU na základě výše uvedeného uzavřel, že předzaškrtnuté políčko není dostatečným projevem vůle pro nesplnění nároku na aktivní a informovaný souhlas. Souhlas s přístupem do koncového zařízení přitom nijak nekvalifikuje takto ukládané údaje, ${ }^{138}$ a tudíž není relevantní, zda se jedná o osobní údaje. Vždy však subjekt údajů musí dostat informaci o době uchování cookies a zda $\mathrm{k}$ souborům cookies mají přístup třetí osoby. ${ }^{139}$

Autor: JK

\section{ZÁSAH DO PRÁVA NA OCHRANU OSOBNÝCH ÚDAJOV \\ ZAKLADÁ NÁROK NA NÁHRADU ŠKODY SÁM OSEBE, BEZ NUTNOSTI PREUKAZOVAŤ FINANČNÚ ŠKODU ALEBO \\ NEMAJETKOVÚ UJMU}

Soud: $\quad$ Britský odvolací súd

Věc: $\quad$ Lloyd v Google [2019] EWCA Civ 1599

Datum: $\quad 2.10 .2019$

Dostupnost: judiciary.uk

Pán Lloyd, obhajca práv spotrebitel’ov, podal na britský súd hromadnú žalobu v mene 4 miliónov používatel'ov telefónov iPhone na spoločnost’ Google, ktorá tajne monitorovala ich internetové aktivity medzi augustom 2011 a februárom 2012. ${ }^{140}$ Google v tomto čase implementoval tzv. Safari Workaround, ktorý mu umožnil uložit do prehliadačov Safari na iPhone svoj DoubleClick cookie bez vedomia používatel’a či bez jeho súhlasu. Google tak mohol sledovat aktivity používatel'ov naprieč webstránkami a zbierat’ či vyvodzovat o týchto používatel’och mnohé informácie, na základe ktorých jednotlivé kategórie používatel’ov ponúkal svojim zákazníkom na cielenú reklamu. $^{141}$

\footnotetext{
${ }^{138}$ Bod 108 anotovaného rozhodnutí.

139 Bod 122 anotovaného rozhodnutí.

${ }^{140}$ Bod 1 anotovaného rozhodnutia.

${ }^{141}$ Body 10-12 anotovaného rozhodnutia.
} 
V novembri 2017 požiadal p. Lloyd britský súd o povolenie, aby boli spoločnosti Google doručené procesné dokumenty mimo jurisdikcie súdu, teda v USA, kde má Google sídlo. Táto žiadost̉ bola zamietnutá, avšak z dôvodu novosti žaloby ako aj žalobcom zvolenej procedúry bolo odvolacím súdu umožnené voči tomuto rozhodnutiu podat' odvolanie. ${ }^{142}$

Hlavnou otázkou, ktorú skúmal odvolací súd bolo, či môže žalobca získat náhradu škody za stratu kontroly nad vlastnými osobnými údajmi podla čl. 13 ods. 1 britského zákona o ochrane osobných údajov (d’alej len „DPA“), ${ }^{143}$ ktorým bol implementovaný článok 23 ods. 1 smernice o ochrane osobných údajov, ${ }^{144}$ a to bez toho, aby musel preukazovat’ peňažnú škodu alebo inú ujmu.

Súd dovodil, že zákon o ochrane osobných údajov bol prijatý na vykonanie smernice o ochrane osobných údajov a ked’že táto smernica bola vydaná na vykonanie čl. 8 Charty základných práv EÚ, ktorý ustanovuje právo na ochranu osobných údajov, čl. 13 DPA je potrebné vykladat v kontexte tejto Charty. Charta pritom ustanovuje, že ktokol'vek, koho práva z Charty sú porušené, má právo na účinný opravný prostriedok. ${ }^{145}$ Zároveň sa súd oprel o rozhodnutie vo veci Gulati, ${ }^{146}$ podl’a ktorého má žalobca právo na náhradu škody bez dokazovania peňažnej straty alebo inej ujmy za civilný delikt zneužitia súkromných informácií. Podl’a súdu tak môže byṫ žalobcovi priznaný nárok na náhradu škody za stratu kontroly nad osobnými údajmi, a to aj v prípade, že mu nebola spôsobená finančná ani nemajetková ujma. Iba týmto spôsobom získajú jednotlivci efektívnu ochranu pred porušením ich práv garantovanú Chartou. ${ }^{147}$

Rozsudok výrazne posilňuje pozíciu fyzických osôb, ktorých právo na ochranu osobných údajov bolo porušené, nakol'ko pri uplatňovaní svojich nárokov za stratu kontroly nad svojimi osobnými údajmi na britských

\footnotetext{
${ }^{142}$ Bod 14 anotovaného rozhodnutia.

143 The Data Protection Act 1998.

${ }^{144}$ Smernica Európskeho parlamentu a Rady 95/46/EHS z 24. októbra 1995 o ochrane fyzických osôb pri spracovaní osobných údajov a vol’nom pohybe týchto údajov.

${ }^{145}$ Bod 42 anotovaného rozhodnutia.

146 Gulati v MGN Limited [2015] EWCA Civ 1291.

${ }^{147}$ Bod 70 anotovaného rozhodnutia.
} 
súdoch už nebudú musiet preukazovat škodu alebo inú nemajetkovú ujmu, na druhej strane však uvedené znamená vyššie riziko litigácii a následných nákladov pre prevádzkovatel’ov, ktorí porušili svoju povinnost̉ v zmysle DPA.

Autorka: PV

Toto dílo lze užít v souladu s licenčními podmínkami Creative Commons BY-SA 4.0 International (http://creativecommons.org/licenses/by-sa/4.0/legalcode). 